International Journal of Linguistics, Literature and Translation

ISSN: 2617-0299 (Online); ISSN: 2708-0099 (Print)

DOI: $10.32996 /$ ijllt

Journal Homepage: www.al-kindipublisher.com/index.php/ijllt

\title{
Maupassant's The Horla is a Portrayal of Human Frailties and a Critique of Anthropocentrism: An Ecocritical/Deep Ecological Perspective
}

\author{
Mohammad Afzal Hossain 8 (D) \\ Lecturer, Department of English, Mawlana Bhashani Science and Technology University (MBSTU), Bangladesh \\ $\triangle$ Corresponding Author: Mohammad Afzal Hossain, E-mail: afzalmbstu19@gmail.com
}

\section{ARTICLE INFORMATION}

Received: May 08, 2021

Accepted: June 14, 2021

Volume: 4

Issue: 6

DOI: $10.32996 /$ ijllt.2021.4.6.27

\section{KEYWORDS}

Anthropocentrism, Anthropomorphic, Ecojustice, Guy de Maupassant, The Horla, Ecocriticism, Ecosophy, Deep Ecology, Nature Writing.

\section{ABSTRACT}

This research analyzes how nature, human and non-human, have been represented in Guy de Maupassant's short story The Horla through an ecocritical lens. In its fundamental form, the ecocritical theoretical framework investigates how nature, landscape, and places have been represented in a literary text and explore how human and non-human interrelations have been portrayed. In this story, Maupassant has portrayed nature as a positive, healing force and delved into the anthropocentric and anthropomorphic constructivist attitude to non-human, invisible, emergent being, in this context, the Horla. The narrator's anthropocentric world view has denied justice toward Horla to exist, fearing he will shake the human-centred ecological hierarchy. According to the Deep Ecological philosophical position or ecosophy, all things, including spiritual being that cannot be seen, are interconnected and have their necessary position in various modalities of Nature. Denial of the existence of a new emerging entity and the inability to schematize and adopt it will destroy the new being and the human race itself. The paper has deployed two major research methods; textual analysis and archival method. Apart from these two methods, discourse analysis method has also been used where deemed relevant and necessary. The paper finds that The Horla is not merely a generic horror story that has portrayed the inner psychological state of the narrator in a fantastique manner but also an expository one of human frailties and human denial of a being that deemed more intelligent and perfect than the human being, fearing to lose the anthropocentric dominance.

\section{Introduction}

Environmental literary and cultural criticism has undergone tremendous evolution since its formal beginning in the USA in the late 1980s and the UK in the early 1990s, demarking two national variants of ecocriticism or green studies (Barry, 2020, p. 248). Since then, this mode of seeing literature has received many inflexions and derivational trajectories. Nevertheless, almost every existing critical and theoretical school has adopted and appropriated this environmental train of thought in their existing theoretical framework. As a result, Marxist environmentalism, ecofeminism, third world environmentalism, and other critical thought schools have emerged. Besides, many ideas and concepts from environmental studies, evolution studies, ecological studies, climate change studies, globalization and global warming, carbon emission and pollution and industrialization have been imported to environmental humanities to better understand the modalities of literature in environmental narratives.

"Simply defined ecocriticism is the study of the relationship between literature and the physical environment" (Glotfelty, 1996, as cited in Barry, 2020, p. 248). Nayar (2009) summarizes ecocriticism as a critical mode that looks at the cultural and literary texts from twin perspectives of; what attitude nature is represented and how the rhetoric is deployed to representational practices.

K C AL-KINDI CENTER $\mathbf{R}$ D FOR RESEARCH Your gateway to world-class research

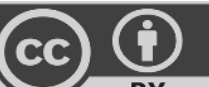

Published by Al-Kindi Center for Research and Development, London, United Kingdom. Copyright (c) the author(s). This open access article is distributed under a Creative Commons Attribution (CC-BY) 4.0 license 
Deep ecology as an environmental philosophy is also used to analyze the environmental concerns represented in a literary text. The central argument of the Deep Ecology philosophy or "ecosophy" is based on "the eco or bio-centric worldview rather than human-centric or technically called anthropometrism" (Nayar, 2009, p. 246).

Norwegian Philosopher Arne Naess developed the concept of Deep Ecology in contrast to Shallow Ecology as a form of ecological philosophy. Naess believed, "humans could only attain realization of the Self as part of an entire ecosphere" (Schwarz, 2009). Naess has outlined some central tenets of "ecosophy" of which "human forms must expand to include more of the others and "there has to be an emotional relation with and response to nature and not merely a rational -intellectual one" (Naess, 1973, as cited in Nayar, 2009, p. 246) are the most relevant ones for this present study. Nayar (2009), in his discussion of Deep Ecology philosophy of Naess has commented that there is a "gesture at a certain spiritual tendency in deep ecology" and this spiritual tendency in deep ecology makes itself applicable in analyzing the invisible being Horla considering him as an emerging element in Nature.

This paper has considered the binary concepts of ecocentrism and anthropocentrism of Deep Ecology philosophy as a central argumentative sphere. The emerging new being in The Horla has been considered a spiritual being (invisible), considering deep ecology's spiritual turn, which also deserves to occupy its position in Nature and ecology. Only an ecocentric worldview can accommodate this being and avail justice for it to exist. However, in The Horla, anthropocentric attitude and rational dominance devoid of any emotion have tried to kill or killed this new being with fire, exposing the inherent frailties of humans. Consequently, this non-accommodative and denying human attitude brings catastrophe to Horla and the entire ecosphere, at least metaphorically.

"A monstrous pyre in which human beings were burning, and he (Horla) was burning too, he my prisoner, the new being, the new master, the Horla"(Maupassant, 1971, p. 343).

Ecocriticism as a theoretical intervention has repudiated the very foundation of the culture and Nature dichotomy laying bare the raw natural elements, the elements as they are, in literature in contrast to "constructedness". It has also shed light on binarism of man-made and god-made reality challenging the idea that everything is "socially and linguistically constructed". This modality of ecocriticism gives further opportunity to read The Horla ecocritically, considering Horla as an emerging Natural, not culturally constructed being, in the realm of ecology betraying the anthropocentric human frailties.

Before the emergence of ecocriticism accompanying posthumanism as "ecocriticism and posthumanism are parallel and potentially overlapping fields", Nature was used in literature to present it as though Nature is also man-made and naturalized (Feder, 2014, pp. 225-226). "Nature is nothing more than an anthropomorphic construct created by Wordsworth and the rest for their own purposes" to disguise the inherent "politics of inequality and legitimate inequalities and injustice" (Coupe, 2000, as cited in Barry, 2020, p. 251). This Marxist eco-critique exposes the anthropocentric attempt to manipulate and exploit Nature for the sake of human interest only. Arguably, the human being always attempts to impose humanistic traits and characteristics on non-human to dominate them better. This same practice can be seen in The Horla when the narrator tries to understand this new being by imposing anthropomorphic; human-like attributes on Horla to understand it, to dominate it and kill it.

"As if an invisible hand had twisted it; then break as if that same hand had plucked it...an invisible creature exists besides me which feeds on milk and water, which can touch things, pick them up....therefore endowed with a material nature" (Maupassant, 1971, p. 330).

"He was there sitting in my place, reading" ( p. 336).

The narrator tries to attribute material properties to Horla to subjugate and kill it, if necessary.

"Don't dogs sometimes bite their masters and fly at their throats?"

"He has the upper hand but a time will come.." ( p. 336).

The narrator ponders and waits for a time when he will have mastery over Horla, and his presentiment of slavery will be dismissed.

\section{Literature Review}

In terms of literary periodization and movement, Maupassant belongs to the Naturalist school of the European literary movement. Naturalism in literature denotes human existence and predicament from a deterministic environmental perspective by exploring the relationship between humans and society. Maupassant's naturalistic preoccupation and its application in his literary works have been studied in many pieces of research. 
Tie-sheng (2004), while comparing O, Henry's Police and Hymn and Maupassant's The Necklace, puts forward that Maupassant "prescribes the darkness in man's nature by naturalist techniques" but "they (O Henry and Maupassant) both discuss the man's predicaments for existence in view of human nature and man-society relation, presenting the aesthetical mechanism of tragedy".

In The Necklace and other works like A Duel and The Devil, Maupassant has experimented with the human presentiment in relation to society and its contexts like war and politics. As in other short stories, this aesthetical mechanism and apparatus of tragedy have also been used in The Horla. The self-aware and seemingly reasonable narrator can be described as a tragic hero who suffers due to an invisible being and eventually thinks of committing suicide to evade the being's presence and influence.

Many other researchers of Maupassant have studied his literary works from various theoretical and critical points of view. Some have taken the whole of Maupassant into their analytical endeavour, and some have worked on a particular piece of work like one novelette or one short story.

Greimas (1988) has critically investigated and scientifically explored almost all of Maupassant's works, including Two Friends, from a semiotic perspective. In his book titled Maupassant: The Semiotics of Text: Practical Exercises, he proposes that "The reading of a literary tale can be seen as a series of demonstrations, that is to say, as an illustration of encounters between a semiotician, who interrogates and manipulates the text, and the text, which sometimes offers up its opacity, sometimes its transparency, simply reflecting the multi-faceted interplays inscribed in it" (Greimas, 1988, p. 23).

Similarly, Maupassant's The Horla has a multi-faceted interplay of meaning instilled within its textual realm that can be retrieved and read from an ecocritical perspective. Maupassant's literary genius can offer many possibilities to read his short story The Horla from Nature and environmental perspective as he has already delved into the Nature of human being, taking inspiration from Nature. In The Horla, it is found that these two natures have interconnectedness and play an essential role in the wellbeing of both Nature and Human Nature.

Gregorio (2005) has explored and traced Darwinian concepts in the fiction of Maupassant. In The Horla, there are explicit allusions to the Darwinian concept of evolution while the narrator tries to understand this new being. In his book Maupassant's Fiction and the Darwinian View of Life, Gregorio asserts, "Evolutionary thought had already begun to capture the imagination of thinkers and writers by the time Maupassant arrived on the literary scene". He further emphasizes, "Some things in Maupassant make sense only in the light of evolution" (Gregorio, 2005, p. 2). The work of Gregorio ascertains that there are elements of the Natural world and Natural Laws in the fiction of Maupassant, and this implies that his work in this context, The Horla can be read if not as an eco-fiction but certainly as an ecology aware literary production where Nature has been positively presented as a healing force and origin of a new being.

What Gale (2016), in his book A Study Guide for Guy de Maupassant's "Boule de Suif" has observed, can very well be projected to the narrator's predicament sketched in The Horla, though from a slightly different angle. Gale observed about "Boule de Suif" that "The title character is caught in a repetitious cycle of self-examination that has forced her into a circular ethical conundrum" (Introduction). The narrator of The Horla is also caught in a seemingly eternal cycle of rationalization within his mental realm about the existence of Horla, the invisible new emerging being. The narrator of The Horla, unlike the protagonist of Boule de Suif, who is in a moral dilemma, is in a critical situation about the dichotomy of reason-unreason, natural-unnatural, empiricalspiritual.

Jones (2017) has elaborated on the issues of human-animal encounters and literary depictions of the human-animal relationship in his essay on "Colonial travelogues by Gautier, Fromentin, Lorrain, Loti and Maupassant". Jones selected travel literature Au Soleil or Under the Sun of Maupassant for analysis. In line of this thought, the encounter of human-nonhuman being has also been portrayed in The Horla. This new being named Horla has come to France from Brazil across the Seine on a three-master white ship. The story starts with this encounter and revolves around the development of human-nonhuman interface, revealing human frailties and weaknesses in the face of an emerging new force more potent in Will than human beings.

"Highlighting their conquering mindset, the travelers feel the need to write in great detail about these encounters which must be textualisés [inscribed], rationalized and thus safely "contained" in order to be intellectually possessed by the travellers." (Jones, 2017, p. 282).

The same conquering mindset can be found in The Horla's narrator, who engages himself in rationalizing the encounter with Horla and the effect "he" has exerted on his mind to over-will and internalize the influence. The narrator's intellectual and rational attempt to schematize the emergence of a new being and its influence implies how the anthropocentric mindset excludes anything more powerful than human beings, denying the being's basic right to exist in the ecosystem. The narrator sets fire in his house to annihilate Horla as he could not accept its existence and influence, which appears more willful than the narrator, than a human being. 
Usher (2019) has explored the question of how 'contemporaries consider[ed] the French Wars of Religion (1562-98) in environmental terms' in his essay, implying the emergence and application of French ecocritical praxis. Maupassant, along with his contemporaries, considered environmental and natural world issues in their literary texts. Maupassant's environmental awareness and preoccupation with natural laws have also been reflected in The Horla.

Lewter (2019), in his essay, has outlined the use of green spaces in Guy De Maupassant's works from 1880 to 1886 . He has considered Maupassant's four short stories and one novel (Bel Ami) to locate Maupassant in the French Nature writing landscape. "Although these works and, indeed, Maupassant, have never before been considered as early examples of what we now call nature writing, they can arguably be considered as relevant precursors to this movement in more contemporary French literature" (Lewter, 2019, p. ii-iii).

Lewter argues that the green spaces have a particular beneficial psychological impression on the Maupassant's characters. The protagonist and other characters visit green spaces either intentionally or unintentionally. Lewter further emphasizes that Maupassant deserves an important place in the history of French Nature writing as his childhood -learned a profound appreciation for Nature, sea, landscape, flora fauna, and green spaces have been projected in his literary works.

Brossilon (2017) has examined the theme of isolation, alienation and annihilation in Maupassant's selected short stories, including The Horla. In these selected stories, self-isolating bachelor protagonists go through anxiety in the face of social changes like change in gender roles and social structures. Gradually these protagonists are confronted by their ghostly "Other" (Le Horla), and finding no livable psychic or social place, they become '"hors la"; out there or outsider (Brossilon, 2017, p. 1).

Hadlock (2003) has also discussed this aspect of "otherness" and selfhood construction along with the thematics of madness in The Horla. He has considered the first published version of the tale where the narrator tells his story sitting in an asylum. Hadlock also discusses the dichotomy of normalcy and ab-normalcy, sanity and insanity by locating the story that tells a "narrative of confronting the inexplicable primal otherness an out there (hors la) that cannot be reconciled with our models of a sane and rational self" (Hadlock, 2003, p. 47).

From the preceding literature review, it is evident that many researchers have conducted their study on various aspects of environmental and ecological concerns of Maupassant's works and Maupassant's works can be read and analyzed from an ecocritical point of view. However, no significant study has been conducted on The Horla from an ecocritical perspective. This paper has attempted to read The Horla from an ecocritical perspective to discover how humans have denied ecojustice to Horla, an emerging new being in Nature. The paper has also explored the anthropocentric attitude of humans, betraying humankind's inherent weaknesses and frailties.

\section{Methodology}

The primary text Maupassant's The Horla has been critically analyzed from an ecocritical theoretical framework deploying two major research methods; textual analysis and archival method. Besides these two methods discourse analysis method has also been used where deemed relevant and necessary. But textual analysis method has mostly been used as deemed most appropriate for this paper's scope and purpose. "Textual analysis is a methodology that involves understanding language, symbols, and/or pictures present in texts to gain information regarding how people make sense of and communicate life and life experiences" (Allen, 2017, p. 4). Written texts, symbolism, imagery, simile, metaphor, allusions, allegorical and analogical elements of The Horla have been textually analyzed to understand the portrayal and representation of human frailties and Maupassant's critique of Anthropocentrism. Messages and meaning derived from textual analysis have been later connected to larger historical, cultural, political, ethical contexts as "broader social structures influence the messages present in the text under investigation" (Allen, 2017)

\section{Results and Discussion}

The Horla was initially published as "Lettre d'un fou" ("Letter from a Madman") in 1885 and was later revised, retitled and republished, told from a doctor's point of view as "Le Horla" in 1886. The story went through yet another revision and finally published in a definitive form in 1887. Guy de Maupassant is considered an innovative precursor of first-person psychological fiction and considered the father of modern French short story of Naturalist school.

The Horla by genre falls into the broad category of horror fiction or fantastique. To validate this classification, many horror elements found in the text have endowed this short story with the literariness of a horror narrative. Other elements in the text can be implicitly and explicitly related to various levels of interpretation ranging from biographical, contemporary social, political, economic, and scientific discoveries and innovation. However, to maintain the paper's focus, relevant environmental, natural and scientific elements inscribed in the text have been considered to discuss and explicate The Horla from an ecocritical perspective. 
This ecocritical reading has rendered a well-founded understanding of the anthropocentric human weakness and human denial of the existence of inexplicable and invisible forces that threaten the ecological human supremacist position in Nature.

Barnhill (2010) has outlined ten elements of nature writing. These elements can be used to evaluate to what extent The Horla can be discussed through an ecocritical lens. These ten elements are- "accounts of nature (natural history or descriptions of particular scenes)"; accounts of "personal experiences in nature"("solitary" or with other beings); "the social experience of nature (present communities, history, cultural ecology, or imaginary communities)"; "philosophy of nature (metaphysical view of nature, ontological status, or ethical relation to nature"); "an ecological psychology or natural psychology of the mind"; "language, knowledge and their relation to the natural world"; "philosophy of the human"; "ecosocial philosophy"; "praxis (or actions taken in response to the experience, ideas, and values outlined in the previous elements)"; and "spirituality" (Barnhill, 2010, pp. 279283).

All of the elements of nature writing mentioned above can be found in The Horla. Though this paper does not directly intend to discuss The Horla as a nature writing literary piece, the elements and principles of nature writing can be well applied to ecocritical theoretical premises used in this study.

Human has long denied the existence of being that cannot be seen or recognized through senses. The philosophical debate between empirical and rational/idealist schools has variedly discussed the importance of human senses in human epistemology and understanding of themselves and the external world. In The Horla, the human senses' capacity to help humans derive exact knowledge has been questioned and tried. The rational faculty of human being in the face of a more powerful force has also been excavated.

Though the account of these has been presented chiefly through the monologue of a narrator who has frequently been mentioned as an "unreliable narrator" in various literature, in a diary format, , the way the narrator tries to understand Horla and its effect on his mind through contemporary knowledge of scientific experimentation (Mesmerism), Darwinism (Evolution), religion, books ( Doctor Hermann Herestauss's treatise on the unknown inhabitants of the ancient and modern worlds), discussion with the "monk" and Doctor, and his sincere attempt to cure himself through changing of places (going to Paris, taking a vacation, strolling in the forest and on the bank of Seine etc.) prove to be the doings of a sane and rational man whose only folly seems to be the denial of the existence of forces that cannot be seen but has the capacity of exerting an immense effect on his mind and appears to be more powerful in will than himself, than human.

The following discussion has examined and articulated different excerpts of the text, considering the meaning and implication they provide, for the understanding of The Horla from an ecocritical perspective. This perspective gives an in-depth insight into human frailties and Maupassant's intentional critique of anthropocentrism.

\section{The dichotomy of Nature as a Healing Force and Denial of Supernatural- Horla}

"There can be no doubt that everything depends on places and settings.....we fall irresistibly under the influence of our surroundings...the weather is glorious. I spend my days watching the Seine flow by"(Maupassant, 1971, p. 329).

Maupassant has portrayed different natural elements and places as holding healing energy for the worried and anxious protagonist. The narrator deems the escape to a forest or Seine or Hills and riverbank from his house as beneficial for his mind. These romantic elements have worked as a temporary respite for the narrator from the haunting of the invisible being. Nature reinvigorates the narrator with new energy and spirit.

"I went for a walk in Roumare Forest. The fresh air, the clear mild air, full of the scent of leaves and grass, was pouring new blood into my veins, new energy into my heart" ( p. 317).

"Twenty four hour in Paris have been enough to restore my mental equilibrium" ( p. 322).

After frequenting Paris, Hills, Forests, the narrator feels that he has been cured of his mental illness, thinking that no invisible being is draining his life energy out of his throat and lips "like a leech". It is his mind doing tricks on him.

"The sunshine covered the river with light, made the earth a place of beauty, and filled my heart with a feeling of love for life, for the swallows whose swift flight rejoices my eyes, for the riverside grasses whose whispering charms my ears" ( p. 332).

"What a splendid sight meets your eyes when you arrive at Avranches. The town stands on a hill. an immense bay stretched out before me as far as the eye could see...in the midst of this vast yellow bay under a pale golden sky"( p. 318).

"I am completely cured" (p. 317). 
The narrator further tries to rationalize that loneliness and solitude is the reason for his current presentiment rather than the presence and influence of a supernatural entity.

"There can be no doubt that solitude is dangerous for active minds. We need to be surrounded by men who think and talk. When we are alone for any length of time, we people the void with phantoms. ( p. 323).

Next, the narrator thinks he has been under the influence of some sort of hypnotism, denying the existence of Horla-

"I have fallen under one of those well-authenticated but so far inexplicable influences known as suggestions (Hypnotism)" ( $p$. 324).

These thinking processes expose the beneficial effect of Nature on humans and betray the rational attempt to deny another (super)natural force, Horla. From the beginning of the story, the tension between these two aspects of natural and supernatural proceeds in a conflicting manner until it is resolved that natural elements like river, forest hills, and supernatural or spiritual elements like Horla are supposed to co-exist co-create. Denial to one to exist causes imbalance in the natural order as everything has the power to exert influence on both human and Nature.

"Everything we brush past without knowing it... has swift, surprising and inexplicable effects on us, on our senses, and through them on our ideas, on our very hearts" ( p. 314).

However, further appreciation for Nature by the narrator follows but denying Nature's counterpart the spiritual and supernatural Horla. Horla becomes a metaphor for all the invisible forces of Nature. These forces exist and exert their impact on human and the universe unknowing of human. And once they get manifested as Horla did, human being failed to accommodate it. They deny their existence, fearing human annihilation by the more powerful force. The invisible forces like global warming or climate change cannot be sensed or seen, but they exert a tangible impact on the human being and all levels of the ecosphere.

\section{The Portrayal of Human Frailties}

"How profound it is, that mystery of the Invisible; we cannot fathom it with our wretched senses" ( p. 314).

This assertion implies an interconnectedness between visible and invisible entities. The narrator delves into the invisible realm by questioning the power of human senses that cannot perceive many things due to the limitations in the senses. The narrator further points toward essential flaws in human perception about the invisible forces and regret not having the proper capability to understand other beings of heaven and earth. "There are more things in heaven and earth, Horatio, than are dreamt of in your philosophy" (Shakespeare, 1991). Moreover, even if the forces or being from the invisible come existent to human senses, they tend to deny it.

"If only we had other senses which could work other miracles on our behalf, how many more things we could discover around us" ( p. 315).

Unable to understand Horla with limited human sense and capacity, the narrator harshly criticizes human capability, deeming that animals have more perfected senses than human beings in many regards.

"With our sense of smell, which is feebler than that of any dog.. or with our taste which can barely detect the age of a wine" ( p. 315).

The narrator goes further in finding out the human frailties and criticizing human limitations-

"How weak our minds are, and how easily they are shaken and troubled as soon as they are confronted with a tiny incomprehensible fact. Instead of coming to the simple conclusion: 'I don't understand because the cause escapes me', we promptly imagine terrifying mysteries and supernatural powers"! ( p. 323).

Maupassant has even pointed out the fundamental limitations in human experimental sciences. The narrator engages in an experiment to find out the Nature of Horla in which he partially succeeds. "I carried out the same experiment with the same result" that Horla drinks milk and water and can pluck and smell roses ( p. 322).

"an invisible creature exists beside me which feeds on milk and water, which can touch things, pick them up....therefore endowed with a material nature" ( p. 330).

His seeming success in finding out the attributes and nature of Horla sheds light on the human attempt to understand everything by imposing human qualities on them. This anthropomorphic attitude proves to be fallacious when the narrator 
thinks to kill himself after figuring out that Horla cannot be killed with fire because Horla has more perfected attributes than human beings. This experiment mindset also sheds light on the contemporary development in science. The Darwinian knowledge of evolution and natural selection was widespread among wealthy socialites like the narrator. This experimentation also betrays how the existence of a new depends on overtly scientific experimentation and validation, thus denying the essential spiritual being like Horla to be existent.

Narrator concludes echoing the essence of Nietzschean concept of "Ubermensch" or "Superman" that Horla cannot be destroyed because "he has reached the limit of his existence". The traces of Fredrich Nietzsche's works especially of Thus Spake Zarathustra in Maupassant's The Horla are very evident in the discussions on Will, Willpower and Overpower. "I can no longer will anything; but someone wills things for me-and I obey" (Maupassant, 1971, p. 333). The narrator of The Horla is anti-thetical to Superman. "Man is something that is to be surpassed" (Nietzsche, 1958). This posthumanist line of thought posits that human has frailties and weaknesses to overcome and The Horla has outlined those human frailties as Nietzsche (1958) philosophizes, "Man is a rope stretched between the animal and the Superman-a rope over an abyss".

Nietzsche in his book Ecce Homo: How One Becomes What One Is published in 1908 expressed his fondness of Maupassant. "To point to one of strong race, a genuine Latin, of whom I am particularly fond, Guy de Maupassant" (Nietzsche, 1908, p. 39). Ecce Homo is broadly focused on the philosophical perspective of Nietzsche on human being which has also been reflected in Thus Spake Zarathustra (1958). The Horla can be considered Maupassant's perspective on human beings, laying bare the human weaknesses and critiquing anthropocentrism, thus exposing human vulnerability instead of idealized Superman or Horla imagery. Horla is Maupassant's Ubermensch.

"For we humans are so weak, so defenseless, so ignorant, so small on this speck of dust spinning around in a drop of water!" opposed to "its (Horla) Nature is more delicate, its body finer and more finished than ours" (Maupassant, 1971, p. 339).

\section{Anthropocentric, Posthumanist and Apocalyptic Elements}

Feder (2014) argues that "ecocriticism and posthumanism are parallel and potentially overlapping fields" and the "apocalyptic post of posthumanism suggests that the age of Man may lead to an age without human beings and great many others". Moreover, "at some point we or the world became posthuman" "not only in the form of the Anthropocene but also in the age of the new man" ( Feder, 2014, p. 225-226). Feder's argument connecting ecocriticism, Anthropocentrism, posthumanism and apocalypticism can directly be stretched to The Horla for understanding how emergence of new being Horla exposes different layers of anthropocentric, posthumanist and apocalyptic elements, while some excerpts from the text are taken into consideration.

"There existed on this earth creatures other than ourselves" hidden from human knowledge and "one of them, sooner or later, on his way through space, appear on our earth to conquer it, just as the Normans once crossed the seas to subjugate weaker peoples"(Maupassant, 1971, p. 335).

Once these hidden creatures materialize to human perception, the struggle for dominance over each other leads toward both posthumanist and apocalyptic earth. "A new being! Why not? It was assuredly bound to come! Why should we be the last?" ( $p$. 339).

The narrator ponders, "But who is he, this invisible being that rules me, this unknowable being, this rover of a supernatural race?" and gets the answer, "as if he were shouting his name in my ear...Horla I heard it...the Horla.. it is he, the Horla... He has come!".

The anthropocentric world view mostly operates through a model of master-slave binary relationship. Maupassant has delved into master-slave and human-animal relationships through the narrator's internal psychological and intellectual process. Narrator sees the emergence and gradual overcoming by Horla of his will as the revenge taken on humankind. "Nothing could be truer than Voltaire's dictum: God made man in his own image, but man has taken his revenge in kind" ( p. 325).

Man has long exploited other species and made them "his chattel, his slave, and his food, by the mere power of his will". And Horla has come to change this master-slave relationship to make the earth eco-centric and bio-centric other than anthropocentric. "Man has killed the lion with an arrow, with a spear, with gunpowder; but the Horla will make of man what man has made of the horse and of the ox using the weapons of this new Lord, with the imposition of a mysterious will upon the enslaved minds of man" ( pp. 337-338).

Man's denial and negligence to other species to exist and flourish for "a fear of a new being, stronger than himself, his successor in this world" exposes not only the rudimentary level of human intelligence but also other ideological, cultural and religious acquisition including the very concept of God and its origin. Horla stretches mankind to posthumanist state, not even excluding post-God state as "the legend of God" was "devised by a terrified (human) brain". 
"As long as his (human) intelligence remained in a rudimentary state, this obsession with invisible phenomena took crude and simple forms. That is the explanation of the popular notions of the supernatural, the legends of wandering spirits, fairies, gnomes, ghosts - I would even say the legend of God as well, for our concepts of the artificer creator, from whatever religion they come to us, are really the most uninspired, stupid unacceptable inventions ever devised by a terrifying brain"; "Oh! my God! my God! Is there a God?" ( pp. 324- 333).

Furthermore, the narrator, alluding to the Darwinian concept of "natural selection" and "survival of the fittest", tries to confirm the emergence of a new species with perfected elements which cannot be prematurely destroyed like human and signals the end of anthropocentric narrative for a posthumanist and ecocentric worldview with a stake on apocalyptic consequences of "the world coming to an end?"

"There have been so few different creatures in this world, from oyster to man. Why not one more, once we have reached the end of the interval between the successive appearances of the various species" ( $p .330$ ).

"Premature destruction? That is the source of all human dread. After man, the Horla.... he who shall die only at his appointed day, hour and minute because he has reached the limit of his existence" ( p. 344).

"Now I know, I understand. Man's reign on earth is over" ( p. 337).

\section{Conclusion}

From the foregoing explorative discussion on ecocriticism, anthropocentrism, posthumanism, and textual analysis of The Horla, it can be concluded that Maupassant has portrayed human weaknesses and frailties by creating a foil, a potentially more powerful being Horla and produced a critique of anthropocentrism with subtle signal to a post-anthropological ecocentric, biocentric and ecocultural earth. Maupassant has also commented in a subtle way on the issue of anthropodenial and anthropomorphism through the sketch of the narrator's psychology and attitude to Horla. Textual evidence from The Horla as discussed in this paper, show the ecocritical and ecocultural awareness on the part of Maupassant, evident in his treatment and representation of Nature. Through the veins and arteries of a generic horror narrative The Horla, Maupassant has inscribed human-nonhuman and nature-culture dichotomies to urge human being to be more accommodative and acknowledging to schematize "Other" beings, like the Horla, of Nature for developing a relationship of co-existence and co-creation rather than dominance and destruction.

\section{References}

[1] Allen, M. (Ed.). (2017). The SAGE encyclopedia of communication research methods. Sage Publications.

[2] Barnhill, D. L. (2010). Surveying the Landscape: A New Approach to Nature Writing. Interdisciplinary Studies in Literature and Environment, 17(2), 273-290.

[3] Barry, P. (2020). Beginning theory: An introduction to literary and cultural theory. Manchester university press.

[4] Brossillon, C. (2017). The figure of the 'Horla'in Guy de Maupassant's short stories: from isolation and alienation to annihilation. Dix-Neuf, 21(1), 16-30.

[5] Coupe, L., \& Bate, J. (Eds.). (2000). The green studies reader: From romanticism to ecocriticism. Psychology Press.

[6] De Maupassant, G. (1971). Selected Short Stories. Penguin.

[7] Feder, H. (2014). ecocriticism, Posthumanism, and the Biological Idea of Culture. The Oxford Handbook of Ecocriticism, 225-240.

[8] Gale, C. L. (2016). A Study Guide for Guy de Maupassant's" Boule de Suif". Gale, Cengage Learning.

[9] Garrard, G. (Ed.). (2014). The Oxford handbook of ecocriticism. Oxford Handbooks.

[10] Glotfelty, C., \& Fromm, H. (Eds.). (1996). The ecocriticism reader: Landmarks in literary ecology. University of Georgia Press.

[11] Gregorio, L. A. (2005). Maupassant's fiction and the Darwinian view of life (Vol. 143). Peter Lang.

[12] Greimas, A. J. (1988). Maupassant: The semiotics of text: Practical exercises (Vol. 1). John Benjamins Publishing.

[13] Hadlock, P. G. (2003). Telling Madness and Masculinity in Maupassant's" Le Horla". L'Esprit créateur, 43(3), 47-56.

[14] Jones, C. (2017). Ecocriticism avant la lettre: human-animal encounters in colonial travelogues by Gautier, Fromentin, Lorrain, Loti and Maupassant. Studies in Travel Writing, 21(3), 278-292.

[15] Lewter, M. C. (2019). Parisian green spaces in the work of Guy de Maupassant from 1880-1886 (Doctoral dissertation, University of Alabama Libraries).

[16] Nayar, P. K. (2009). Contemporary literary and cultural theory: From structuralism to ecocriticism. Pearson Education India.

[17] Nietzsche, F. (2009). Ecce homo: how to become what you are. Oxford University Press.

[18] Nietzsche, F. W., Bozman, M. M., \& Tille, A. (1958). Thus Spake Zarathustra. Dent.

[19] Shakespeare, W. (1991). Hamlet:[1604]. Oxford Text Archive Core Collection.

[20] Tie-sheng, H. U. (2004). Man's Nature and the Society He Dwells in_—Contractively analyzing the two novelettes respectively by O. Henry and Guy de Maupassant [J]. Academic Exchange, 2.

[21] Usher, P. J. (2019). French Ecocriticism: From the Early Modern Period to the Twenty-First Century. Edited by Daniel A. Finch-Race and Stephanie Posthumus.

[22] Walter, S. (2009). "Obituary: Arne Næss". The Guardian. Guardian News and Media. 
Page | 237 